\title{
Russian culture and management of meaning in introduction of political influence in Ukraine
}

\author{
Mykhailo Sazhniev \\ Melitopol Boghdan Khmelnytskyi State Pedagogical University, \\ Ukraine \\ vsegda@ua.fm
}

\section{Joanna Sułkowska}

University of Social Sciences, Lodz,

Poland

jsulkowska@san.edu.pl

Abstract. This paper investigates narratives and ideology of disinformation campaign which Russian Federation launched into information space since February 2014 when undisguised occupation of Ukraine started. At the same time world liberal democracies were also targeted. In this study we examine the role of the national history and people's cultural self-identification in the Russian-Ukrainian conflict. Moscow claimed they started the disguised war against Ukraine to protect 'people who feels a connection to Russian culture'. And this narrative was not just a casus belli, but also the important factor of country's socio-political destabilization. Russian Federation used Russian culture affinity to raise hostilities between people. Disinformation campaign was simultaneously inciting hostility against Ukrainians at the same time portraying 'people who feels a connection to Russian culture' as victims. Common spoken language in Ukraine was used to incite violence and disinformation convinced that those who speak Russian are in peril. While in fact Ukrainian language and culture are country-wide suppressed after Russification period, Russian propaganda stated otherwise. Disinformation campaign was inventing new reality, distorting history and denied Ukrainian ethnocide in 20th century. This campaign brought a number of mercenaries as combatants to the east-Ukrainian battlefield and also turned a number of Russia's propaganda consumers around the world into 'viral carriers' of conspiracy theories.

Keywords: Ukraine, interdependence, cultural situation, disinformation, post-truth.

JEL Classification: F5, F54, F52, Z13 


\section{INTRODUCTION}

Alain Besancon said that "the art of lie is as old as Russia itself", stating that the Russian state and it's ideologies were based on distorting reality and disinformation. Analyzing the 20 century history we observe as USSR and Russian ideology mimic everything they consider worth taking - culture, political system, elections, public organizations, reforms, fight with inequality and injustice. As result people in public were 'role acting' while often thinking otherwise, behaviour of society can be compared with the performance for the Red Cross in 1943 of the Nazis concentration camp Theresienstadt, when humanitarian organizations found no crimes, because people imprisoned there performed show of happy life and hide the terrible reality (Margry, 1992; Stránský, 2011). But USSR proved to be even more skillful in creating images of non-existent reality. The example of such a "historical management of meaning" could be denial of Soviet crimes during Second World War committed in Katyn (Scharf, 2011). The concept of "management of meaning" could create the theoretical frame for manipulation of information in media (Sułkowski, 2015). The objectives of creating, shaping and disseminating false information could be political, but also commercial. Both should be criticized with use of concepts and methods taken out from media studies, sociology and management (for example Critical Management Studies) (Sulkowski, 2019).

The USSR and the Russian Federation used similar methods of disinformation - in 20 century the USSR publicly showed the 'edited' version of reality in government controlled mass-media. But despite the USSR collapsed, methods of deception they used are being used in 21 century and they are hard to study due to lack of undistorted original materials and removal of 'undesired' facts from mass-media (Griffin, 2011; Gessen, 2018). We consider threatening the fact that those instruments of deception and direct influence on public opinion, have become much more influential and dangerous in the modern world. Information is being used as a weapon to bring emotions atop the rational behavior, disinformation creates and integrates in society an 'alternative opinion' based on 'edited reality'. In the Internet era the modern world collided with irrational reality masterfully recreated by the USSR successor - the Russian Federation (Dickinson, 2017). As we witness, in the post-truth world objective free-press is being overwhelmed by disinformation sources. Vivid emotions are overcoming logics and facts, effectively replacing objective reality with disinformation. In response fact-checking the information helps to separate reality from fiction, at the same time lesser attention is paid to methods of distorting the information and ideology that lays within it (Giles, 2017). At the same time Russian media space filled with conspiracy, even open access lectures on 'informational defence', are on country teach listeners to create disinformation and to use its methods in informational warfare (Holopov, 2013).

The study aims to analyze the cultural influence on subjected society, reveals the ideological level of disinformation beyond deliberately misleading ideas and fictional events launched against Ukraine in mass and social media in 2013-2015. It also attempts to points out on Russia's attempt to use modern world cultural challenges to disorient people in target countries on example of Ukraine. The article provides the information on the role of the lies on people's life, demonstrates how it leads to accommodation to this in historical perspective, to create 'double thinking' when public opinion and inner motivation are different and words doesn't mean what they should. Authors witnessed acts of aggression in social media, studied previous disinformation campaigns of USSR and Russian Federation and role of ideological motivation, society atomization and people alienation in igniting the conflict and covering up the aggressive intentions. Author shares the opinion on this topic with (Herpen, 2015) and (Brzezinski, 2000), he believes that democracies in 21 century face the dangerous challenges of authoritarian regimes that use the cultural challenges of postmodernism in modern democracies to weaken and emotionally divide society, create conflict between people. 


\section{IDEOLOGICAL BASIS OF RUSSIAN DISINFORMATION IN WARFARE CAMPAIGN}

Studying 2014-2020 Ukraine-Russian conflict, we started from undisguised occupation of Crimea and disinformation basis for the war in 2013-2015. Since November 2013 Russian propaganda brought a number of fictional facts and distorted ideas into Ukrainian society. People had to bare and identify the truth from disinformation, researches had to find out what role those fictional facts played in Russian disinformation campaign. We focus on some basic terms appeared in Ukraine information space in those days. First of all, we should mention that those terms were never widely used before, but since 2013 people often were named as 'fascists', 'junta', 'Banderites', while pro-Russian militants were named 'separatists', 'People's Militia' (in Russian: Opolcheniye). Those terms have a strong emotional connotation and were used not to describe the situation, but to divert attention from logical perception to emotional unrest, to take hate-speech for granted in social communication. Such strong emotional background was used to made impossible any productive communication, logical perception of information and rational mutual perception of the facts and world itself.

Such terms in Russian disinformation campaign were used in Russian and pro-Russian media before event started to happen and a lot of people did not even know the meanings of terms. Most of them were brought from outside of informational space of Ukraine, to create such 'edited' reality. And yet most fearsome scenario of bringing proclaimed by pro-russian forces chaos to Ukraine failed to work, ideological level worked as was intended to. For example narrative of 'separatism' appeared in mass and social media before people could even understand who was going to separate and from whom, it appeared lately as an idea of 'Crimea separation from Ukraine', but objectively this plan did not work properly in Crimea. On contrary, what happened there was opposite from disinformation proclaimed. There was the legitimate reason to talk about separatism as Crimea Tartarians are really a different nation, they have their own language, culture, history, religion and no native sovereign country. But Majlis and Crimea Tartarians in March 26, 2014 clearly showed that Tartarians were against any Russian initiatives and, on the contrary, supported Ukraine and opposed the Russian Federation attempts to seize the control on administration. Thousands of Tartarians went to Simferopol Parliament to stand against Russia and its narrative of separatism, even despite the fear of Russian military presence as 'little green men' (Rus. - zelyonyie chelovechki), this information was clear for Crimean Tartarians protesters and was considered as personal threat. But despite all odds, meeting in March 26 demonstrated that Russian 'separatism scenario' and even the idea itself was not Crimea Tartarian initiative. Still despite the real situation with native Crimean Tartarians, 'separatism' was widely used in Russian mass-media, replacing appropriate for occupation term 'collaborationism' and hiding the idea of Russia's aggressive actions. But in fact the idea of Crimea separatism appeared to be dead-born. (Radio Svoboda, 2014)

Even later in spite Crimean Tartarians separatism failed, pro-Russian militants in the Eastern Ukraine in Russian and pro-Russian media were called again a 'separatists'. This time there was even no national, ethnic or religion basis to 'separate' but to 'give up' to Russia and go under its full control justified by the disinformation in mass-media. In fact people lived on the native Ukrainian territory, with the Ukrainian language, culture and religion, repressed by previous Russifications. And separatism had nothing in common on the east of Ukraine, the correct description of the situation is 'pro-Russian collaborants'. But term 'collaborants' was used very seldom both in 2014 and in 2020, this term is still very sparse in mass and social media. Thus Russian Federation does not just conceal that they started warfare in 2014, but are also avoiding the term 'collaborant' by all means, opposes it with much effort on political, mass-media, juridical and social spheres. Instead 'collaborant' they switched to the term 'People's Militia', using it to characterize militants from Russia, including military forces and locals who agreed to fight for the Russian interests under Russian command. This term is seldom used even in Ukraine and this fact is disturbing, especially as the law on 
collaborationism was not yet accepted in Ukrainian Parliament and it was proposed not in 2014 but in 2017 only. Correct term and law on collaborationism are not just a politically correct procedure, but also after the adoption it will help to discredit Russian disinformation on 'separatism' around the world. (Lapin, 2017)

Other terms like: 'fascists', 'junta', 'Banderites' are also not just incorrect, but have a strong negative ideological historical connotation. Neither 'junta' nor 'fascists' or 'Banderites' were applicable toward Ukraine and was not widely used before the 2013, the spike of Google search for these terms happened in period from February to October 2014 (Google Trends, 2014). Russian and pro-Russian media brought those terms in the consciousness of people around the globe interconnecting them with Ukrainians thus leveling down the emotional support of 2014 Ukrainian revolution, instead of most popular in Ukraine terms 'dignity', 'independance', terms with negative connotation brought to life emotional association with crimes of Fascist Germany in the 20th century (Disinformation review, 2018). But if 'separatists' is acceptable but not a worked scenario for the Crimea situation, as it was refuted by Crimea Tartarians themselves, the terms 'junta', 'fascists' and 'Banderites' with its bright negative connotation is still being used for mass propaganda. As we study the history of usage of term 'fascists' by Russia's mass-media, we see that it is always used towards any national liberation struggle and is used to name those who opposed the Russian occupation in the 20th-21st. Often 'fascists' was used against those who wanted to proclaim independence for country, conquered by the USSR or the Russian Federation. And while 'fascism' is definitely associated with ultra-right nationalism, it has never been popular in those countries that opposed the Russian Federation or the USSR - Ukraine, Georgia, Latvia, Lithuania, Estonia, Chechnya.

Terms with negative connotation are also meant to dehumanize a victim and shift outer world opinion from victim's side toward the aggressor's interests. Moscow most often choose the term that depicts the extreme nationalism because any national struggle for freedom is disastrous for empire-like state which suppresses all national attributes among conquered people. In 21 century globalized world got used to consider nationalism to be archaic, obsolete and often even aggressive towards foreigners (Fukuyama, 2010). Developed democratic countries has entered the phase of postindustrial economic development in economic and postmodern in culture, due to nationalism which has played it's vital role in forming the state society. Now the postmodern era is shaping future society and often is fighting or changing the modern ideas. In liberal democratic countries this process brings uncertainty to society as we don't know yet what future will be like. But we consider that very important is to maintain fundamental humanistic ideas, prevent accepting nihilizm and 'protest for protest', thus ruining society and devastating national principals of country's culture (Huyssen, 1986). Pivotal is also to support social capital and trust both within the society and in intercultural relations (Sułkowski, 2017; Bilan et al., 2011). And there is also a gap between different world countries - while most European countries were forming national sovereignty since 1648, and in 20 century they became leading democracy, accepted and agreed with the theory of sustainable development, as result nationalism in 21 century is decided to be obsolete compared to globalization processes. Still a lot of countries and territories around the world are living in atomized, tribal or imperialistic societies and they never evolved as national states, thus principles of globalization and sustainable development is seen from different perspective. The Russian Federation rejects modern ideology and perceives national ideas as hostile for its territorial integrity, instead Russian Federation claims its own 'special way', rejects modernization and since 2014, opposing sanctions it declared re-creation of autarky as the USSR was in the 20th century. The world democracies for Russian Federation now are perceived as threat, this approach is similar to the USSR attitude and its "world revolution" to overcome the opponent and as the instrument to conquer the world. After the fall of USSR the biggest country in the world was named a 'black hole' - because of its desire to expand, absorb and destroy conquered nations. But in the 21 st century modern society forgot the USR methods, became vulnerable and nationally unstable, but same as the USSR the Russian Federation still 
remains a dangerous adversary and 'black hole' especially for weakened nations either neighboring or remote world countries (Brzezinski, 2000).

\section{CULTURAL AND HISTORICAL PREREQUISITES TO ASYMMETRIC WARFARE IN UKRAINE}

De-jure 15 new countries appeared on the world map in 1991 as new independent states, but de-facto most of not all of the ex-USSR republics were reborned as national countries. Most are remaining in Moscow "sphere of interests", some even turned back from national freedom to Moscow's political and economic control, from the Commonwealth of Independent States to the Eurasian Customs Union. Mr. Putin's speech in 2005 about "the largest geopolitical catastrophe" represented political goal and Moscow is "collecting land" again, remains the biggest telurocratic empire on the Earth. Since 1991 only Baltic States - Estonia, Lithuania, Latvia did their best to make Russian revenge impossible. They managed to overcome Moscow political influence, consolidated nations, reformed the state, reborn national culture and then became a member of the EU and the NATO. Whilst Ukraine and Georgia are still overcoming political threats of the Russian Federation on own territories and are paying bloody price for freedom fighting against Russian armed forces and pro-Russian militants. On the other hand, we witness as Georgian and Ukrainian nations are trying to break free from the colonial-metropolitan relations, restore national self-identification and dignity - ideological cornerstone of the freedom. The Russian Federation itself does not represent free national federation - any freedom calls, independent democracy or autonomy not controlled by metropoly there are suppressed or prohibited. In Second Chechen War Moscow military suppressed freedom-fight to maintain full political control over the indigenous nation at the same time created new 'donetsk-lugansk nation' in Ukraine with the same goal - to maintain political control over indigenous nation. This concealed war against Ukraine also manifested Russian Federation as terrorist state which grossly violated The Geneva Declaration On Terrorism, 1987.

National-cultural aspect in the 2014 Russian-Ukrainian war plays a major role. The involvement in the occupation of Crimea and ongoing war against Ukraine was "to protect the Russian speaking people". But narrative 'Russian speaking' was spread to distort the understanding of the situation in Ukraine. Despite the fact that Russian language was spread in Ukraine in previous centuries due to Russian occupation and both Russian and Ukrainian language are understandable for Ukrainians, the language situation is represented as conflict and division of the Ukrainians when people cannot communicate with each other due to different languages. In fact there is different problem - Ukrainian language is the only state official language, it is taught in schools and Universities, all movies are shown in Ukrainian, but Ukraine is also living in unrestricted Russian cultural sphere and Russian language. Yet switching from one language to another before the 2014 happened imperceptibly for people and did not require any political protection. For centuries Russian Empire, USSR and Russian Federation did their best to spread cultural influence to all exUSSR countries, including Ukraine. As result the Ukraine culture was suppressed due to the Russian occupation, assimilation and dehumanization of Ukrainians for 400 years, but especially due to period of Ukrainian ethnocide in the 20th century (Khmara, 1975). And while native culture in Ukraine was oppressed, Russian culture and language was spread instead to replace it. The most affected by 'Russification' were big cities and the geographical territories that remained under Moscow's control for a longer period of time.

Since November 2013 Russian propaganda started actively spreading the indoctrinating narrative that Ukrainians are divided on the basis of different linguistic groups, one of which 'Russian speaking' and the other 'Ukrainian speaking'. They never noted that Ukrainians and most of minor nations in Ukraine understand and speak the Ukrainian language no matter which part of the country they live in, whilst Russian is also commonly used as an aftermath of the Russian occupation and is more common for people living in 
cities especially ones on the East of the Ukraine. Cultural or linguistic conflicts between Ukrainians and Russians never happened but disinformation campaign stated otherwise and starting informational and asymmetric warfare in 2014. The whole idea of targeted territory of Ukraine called as 'Novorosia' was based on commonly used language as if this somehow represented national, religious or cultural difference between Ukrainians. But idea felt in 2014 and had to be supported by militants from Russian Federation as volunteers, Russian military and special forces. There were mostly autochthon Ukrainian nation living in own country - Ukraine with no desire to fight each other, just some people were more passively fighting back Russian propagandistic narratives and rejected its militants. Language and culture alone have never been used before to start a war, and it was enough to make people passive since Ukraine didn't actively protect own cultural space and never succeeded in normalized it after Russification period. On strategic level before 2014 Russian cultural influence was not perceived as a existential threat and was not considered to be a major part of national security.

Since Ukraine made minor attempts to protect native language and culture after 1991, Russian culture and language were intensively spread in Ukraine de-facto threatening to turn Ukrainian national culture into a minority in own land. After the independence was proclaimed, Russian culture infiltrated and substituted national with movies and music, books and newspapers, Russian social media such as VKontakte and Odnoklassniki. Russian culture spread widely because no active measures to protect national culture, no national strategy to normalize factual situation with the cultural situation were adopted from the Ukrainian side. As result even after 1991 Ukrainian authors in Ukraine were paid more for content in Russian language, than in Ukrainian, even if was created only for Ukraine. At the beginning of the 2014 war the Ukrainians considered it normal to communicate both: native Ukrainian and foreign Russian language. But as language was never a problem, the worst thing happened - modern Russian culture permeated Ukraine together with the Russian language sources.

People in Ukraine were and still are being indoctrinated to oppose anything of Ukrainian culture, including language. Terror agenda pushes those who believed Russia into the narrative that Russian language will be forbidden and anyone who uses it in day to day life will be persecuted. This narrative is very persistent in news stories, communication in social networks and in interpersonal communication, that message is widespread despite or even intentionally hiding that factual situation with language and culture is opposite - it is impossible to live in Ukraine and not to know Russian language and live in culture they spread. The most widespread language in Ukrainian internet activity is Russian, it is mostly the main language in corporate life and common language in interpersonal and professional activity. At the same time Ukrainian culture is massively suppressed by Russian culture and though Ukrainian language is an only official but the spread of Russian culture and their narratives is overwhelming. Despite being independent since 1991 the history of national dehumanization wich played major role in 20 century still remains barely untouched in self-perception - in popular arts Ukrainians are often portrayed in grotesque satirical form, Ukrainian culture called obsolete in general, in Russian cultural product Ukrainians are ridiculed and humiliated. Since 2014 situation made a turn toward more tolerant attitude towards Ukrainian culture it became apparent that the humiliation of Ukrainian culture was not accidental. But Russian disinformation narratives are still distort factual situation and try to portray that what Russia cultural influence did and still doing to Ukrainians is on contrary - what Ukraine does with the Russians in Ukraine.

Russian military invasion into Ukraine was initiated under cover of the "protection of Russian speaking" and disinformation campaign covering up the ongoing military action insisted that the civil war started in Ukraine due to inner cultural and language conflict. Thus wide spread and unrestricted Russian culture became the cause and justification for invasion and since 2014 it is a threat of socio-cultural destabilization not only to Ukraine but to variety of countries. Russian language is mostly spread among exUSSR countries but Russian culture and ideology is spread even more widely, Russian immigrants or people 
who listen to Russia's media sometime become passionate supporter of Russian actions. And as the precedent with Ukraine worked fine it is plausible that Russian Federation can also want to 'protect' passionate supporters from culture of countries they live in. It is not necessary to be ethnic Russian, but anyone who 'feel relation to Russian culture' are good enough. Russian political supporters live not only in Ukraine, Belarus, Kazakhstan or Baltic states but in Germany, Poland, Bulgaria, Slovakia, in countries and Russian propaganda puts effort to increase their numbers. These people are voters, living in free democratic societies but at the same time Russian media seeds uncertainty and ressentiment denying culture values, nation's history and value of freedom. For Ukraine it is an existential threats, and warning to the rest who ignores culture sovereignty. Still most of the Russian culture bearing people in Ukraine are afraid of the war with Russian Federation, most had no desire to become Russian collaborants. They may mostly use Russian as common, but perfectly understand Ukrainian and Russian disinformation on conflict based on cultural affinity is not perceived as a threat.

And as we see on the example of Ukraine, tactics was based on bringing Russian culture to society, spreading nihilistic ideas, creating own representatives and then officially claiming a political threat to 'people who feels a connection to Russian culture' and the necessity to protect people with all means including military. Those people may not be connected to the aggressor by any trait: not as citizens, not as ethnic Russians, not even as Russian supporters - but they learned modern Russian ideology and stopped seeing danger in the ideology of USSR conquest. And since 2014 this is a sufficient reason for every country to be invaded by another country, especially if country is weakened with any political events. On 24 June 2014 Putin said "Russia will always protect ethnic Russians in Ukraine and those Ukrainian people who feel not only the ethnical but cultural and linguistic connection towards Russia, those who feel themselves a part of Russian world"' ('Natsionalnyi aktsent', 2014), ('BBC News Russkaya sluzhba', 2014). And interpretation of the 'ethnos' in such a way, was a precedent, if ignored, same interpretation can be used by any aggressor as 'casus belli'. The world will never be the same after the interpretation of 'ethnos' in this way, as this interpretation ignores people's national self-identification.

Moscow clearly stated, that they will do anything including usage of military force, to 'protect' anyone who publicly sympathize Russians. (Russia today, 2014), (Sovyet Federatsii Federalnogo Sobraniya Rossiyskoy Federatsii, 2014). They ideologic narrative of language and culture affinity was used to destabilize nation, this distorted meaning of ethnos was used to justify denunciation of international agreements, occupation of foreign territory and beginning of the war. Language and culture affinity is still constantly repeated on all levels of communication including official ones and not just bu Russian Federation. As the modern historical revisionism was reborn in 2014 'people who feels a connection to Russian culture' were proclaimed the main reason to annex Crimea by Russian Federation. Italian ambassador in Ukraine Salvini considered Crimea a legally Russian territory and explained it this way: 'There are some historically Russian areas, in which there are a Russian culture and tradition, and which therefore legitimately belong to the Russian Federation,' (Curridori F., 2018). At the same time Russian spread cultural uncertainty and disinformation in Ukraine, attempting to recruit militants and to break Ukrainian society from inside and mass and social-media technologies became a political instrument in modern informational warfare (Etter L., 2017).

\section{INFORMATION DISTORTION AS THE ALIENATING ARRANGEMENT TO WEAPONIZE SOCIETIES IN THE POST-TRUTH WORLD}

The spoken language cannot characterize people, but culture, they feel relations to, can. Important thing that the Russian Federation creates modern content reflecting their visions and ideology, which penetrate throughout the world, no matter what language people speak. So, we propose to use the term that 
was given to characterizes those people as 'people who feels a connection to Russian culture'. We want to make accents on some very peculiar traits of Russian culture to understand "Russian culture identification". Russians in day to day life often specify themselves not only as a nation but as a state 'without borders', culture of resentment is widely accepted, together with imperialistic belief that Russians are culturally superior to any neighbor nation and have a right to 'teach others' (Medvedev, 2014). Russian 'special path', 'greatness', 'holiness' and similar ideas were widely used in the 2014 Russian-Ukraine war (Besançon, 2017). Putin stated - "the greatest aim for Russians is to die for Mother Russia, as they say - among others death is a beauty" ("na miru i smert' krasna"). Ukraine as a neighboring country is under heavy influence of Russian fundamentalists" ideas which reach targets as people who constantly hear Russian disinformation start to accept ideology of 'Russian world'. Some people start to believe and begin to endorse "special way", considering themselves a part of the Russian empire no matter how is is named now. And for those who accepted Russian cultural values information in Russian media is accepted as truth even if it contradicts personal experience.

In 2014 Ukrainians didn't believe propaganda despite a lot of efforts put in it, and the Russian Federation failed to make enough Ukrainians to wage the real war and kill each other. But Russian disinformation campaign and distortion of reality still poses a political and social danger, as people don't believe what they see, doubt in democracy and in ownselfes, and are guided by negative emotions. "Russian" self-identification is perceived as cultural unity of people living in the Russian Federation or the USSR, and rejection of national self-identification of a conquered nation. Russian culture is based on bearing tortures and torturing others when individual values are less important than official state's aim. Communism was an apotheosis of this anti-individualism and "ressentiment without glory/respect/pride" (Herpen, 2015). Russian presidential election of 2018 showed public support of the regime with $67.5 \%$ voter turnout $76.69 \%$ of whom voted for Vladimir Putin. Russian people voted for the current regime, despite the variety of antidemocratic initiatives, despite or even due to the wars in Ukraine, Syria, sanctions and antidisinformation campaign. We can doubt to a degree in results of this elections, but voters reaction before and after elections indicate that Russian people are mostly satisfied with the results and support the regime, with its wrongdoing and are 'betting on' a strong and deceitful leader (Ross, 2018).

And spoken language was used in Russian disinformation campaign against Ukraine on the basis that people in most countries are often identifying nation mostly by language, while the role of customs and traditions is reduced and not considered to be important in the globalization era (Stokes, 2017). So Russian Federation is forming world mass opinion on the basis that Ukraine is 'separated' by the language, thus 'Russian speakers' belong to the Russian civilization and are of Russian ethnicity. This thesis is repeated not only against Ukraine's attempt to normalize the cultural situation after years of forceful 'Russification', but against all the ex-USSR countries and further substitution of national cultures with Russian language and culture continues. In disinformation campaign methods of pervious Russification are concealed and not much people know why and how the Russian language and culture was spread in neighbor countries. And in information campaign it is not limited to countries neighbouring Russia, publicly declared support of Russian culture is thrown in the information space on a regular basis as for example in Syria (Language Magazine, 2017), (Cunningham, 2017). Thus information becomes viral and is used to expand Overton window, fueling further Russification and increasing the support of people 'who feel relation to Russian culture' (Smetanina, 2017).

Russian culture plays important role in disinformation campaigns. The example of the Dutch UkraineEuropean Union Association Agreement referendum, 2016 showed how effective disinformation campaign can be (Applebaum, 2016). Linguistic and cultural thesis as 'casus belli' is constantly repeated by pro-Russian media, and as result it is considered as valid fact and is picked even in official speech by politicians, for example the opinion of US President Donald Trump (Dickinson, 2018). The post-truth world is a place, 
where people can be proved to consider as normal occupying a sovereign territory on the basis of cultural influence, breaking up agreements, and knowing little to nothing about forceful 'Russification' in the 20th century.

From Russian ethno-social disinformation campaign we can say that they tend to identify a nation only by a spoken language ignoring ethnicity and also are claim that anyone who speaks Russian language should be identified as Russians. Different forms of humiliation are present towards non-Russian cultures, for example even naming Ukraine as territory but not independent country. The cultural Russian tradition is calling "at the Ukraine", considering Ukraine just a territory, but not saying "in Ukraine" as a norm of the Russian language naming a country. In general Ukrainian culture and customs are targeted and humiliated, Ukrainians are considered to be subordinate to Russian people, overt verbal aggression was especially distinct in 2014. Russia also claim Ukrainian history to be theirs and distorts it, proclaiming that Ukraine is a 'failed state' without its own history. This attitude is not just a part of politics and propaganda, but is present in the Russian's chauvinistic attitude towards Ukraine and Ukrainians. In general ex-USSR countries, including Ukraine are perceived as colonies under Russian command (Disinformation Review, 2018).

Desinformation endows obviously criminal intends as "alternative opinion" but at the same time it is dehumanizing the targeted victims, in public blames them guilty and are criminal themselves, thus preventing victim's resistance in advance. Since 2013 we could see this tactics in Ukraine, targeted people are accused crime they didn't do, victim is shocked hearing this accusation and now is an easy targets, the resistance is weakened and symmetrical resistance is limited or prohibited. This method was called as "doppelganger - effect" by Marcel Van Herpen (Herpen, 2015). And it is one of the effective elements of aggression as previous victim demoralization prevents adequate defense, at the same time accusation dehumanizes victim for outer observers who heard distorted interpretation where the victim was called a criminal. In modern Russian culture such an elusive but aggressive dehumanizing behaviour and attitude to the others is called 'gopnik'. The same way Russian terrorism uses all possible methods and means to ensure its vitality at the international level. On the one hand, terror in a rude form violates all possible rights and freedoms of citizens and at the same time, with the slightest signs of retribution, terrorism with two-faced cynicism complains about the infringement of its rights. Right to humiliate, oppress, blame, shame, ruin social reputation, even torturing and killing victims.

We consider that we should not expect from Russians to change the attitude until Russian Federation will became a true national state or a real Federation with democratic liberties and rights for people living in its territories. Also crimes of each involved in aggression and disinformation shouldn't come unpunished and forgotten as then they will be inevitable repeated. Russian is still involved in distorting the truth, creating made-up reality and spreading disinformation on wide scale, because they are lots of people who is afraid that truth about their personal crimes will come out and will be well known. Russian society got used to "double-thinking", to lies and distortion of the reality same way as it was done in USSR for 70 years. But never before USSR had such potent resources to spread lies, as Russian Federation have now with modern communication technologies and Internet. WOrld democracies took actions to oppose it, though disinformation resistance is still based mostly on cybersecurity and fact checking but pays less attention to the ideological narratives which are seeded into targeted society. And this methods and dangers they bring forth are destructive to the fundamental interpersonal communications in society and is a grave danger in a long run (DiResta, 2018). "Divide and conquer" principle has always played its role in the warfare but during the information era the target is not military but society itself, disinformation and destructive aims are hidden behind 'right to have opinion' but as soon as destructive elements are gaining power they silence others and object the free-speech preventing any resistance. And if from the very beginning this 'opinion' was based on distorted facts, on sometimes that not ever happened, then in the end we have groups of people who will not understand each other, propaganda believes will have their own reality with nothing in common 
with the rest of the nation, someday close neighbors will turn into enemies (EU vs Disinformation campaign, 2018). And the more people are covered with this ideological technique the more atomized the whole society will become. The initial 'right to have opinion' is being converted into a right to target and humiliate others, discredit the truth, distort reality and create new narratives based on disinformation thus substituting the real events with the help of modern informational technologies: Books, Press, Movies, TV, Radio, Internet gaining supporters and alienating the nations.

\section{CONCLUSION}

Russia creates conspiracy theory and distort facts, justifying its own aggressive intentions and actions. Russian cultural identification since 2014 appears to be not a national characteristic, but hidden in rethorics imperialistic self-identification. 'Russian' in 21 century is perceived the same way as 'soviet' in 20 century, while national self identification considered hoslie for Russian Federation. Nowadays Russian mass and social-media, even top-politics summarize Russian linguistic and cultural affinity as legitimate characteristic of Russian people, and deny national self-identification of attacked nation. In this study we demonstrated that Russian identification through the 20 century till nowadays, was based on deceiving, resentment and expansionism. Communism was born as an apotheosis of anti-individualism, it thrived for decades and deformed perception of the truth for people lived behind the 'Iron curtain'. After the fall of USSR 'doublethinking' was spread around the world and brought into life a number of conspiracy theories and made possible an ideology of post-truth. USSR manipulation the information methods are still being used by Russian Federation and are targeting liberal democracies weakened by national identity-crisis. Russian Federation started ideological war and not just against Ukraine, but against democracy and national selfidentification in general.

The Russian Federation is enforcing its culture into conquered nations to overcome and ruin it national dignity. Z. Brzezinski compared Russia with black hole, seizing and dissolving heighbour space. Moscow has succeeded in weakening and dissolving national identity of diverse societies in Yakutia-Saha, Siberia, Caucasus, Karelia and it uses the same methods against neighbouring ex-USSR countries. Russian Federation behaves as an empire without a distinct "heartland" and "limitrophe", at the moment it remains the biggest telurocratic state on the earth. It denies and levels down borders of national identity not only within Russian Federation, but also declares abroad territories as a part of Russia and people living there as "Russians". For legitimacy of claims Moscow create such definitions as "Russian speaking people" to proclaim targeted neighbours as Russian nation. National country is endangered if people there are well acquainted with modern Russian culture and use the Russian language, regardless of national selfidentification as Germans, Estonians, Ukrainians, Georgians or any (Hurska, 2018). The Russian Federation as its successors - the USSR and the Russian Empire, unites its supporters inside and outside own borders using resentment, hatred and disrespect, tolerance for the criminal behavior, as result they create "doublethinking" and distort perception of reality.

And especially dangerous disinformation and ideological propaganda is in post-modern era, when Globalism is widespread, nations are considered obsolete. Russian Federation uses this tendency to atomize nations, fills society with disinformation, distorts facts and reality with a variety of methods at the same time pretending to be democratic state. And this tactics are already spreads by other regimes around the world. The Russian Federation has brought to life a new 'alternative-reality game' with its mass and social media, using disinformation in the form of conspiracy theories and myths, which goes viral as, for example, QAnon in the USA (Cillizza, 2018) or conspiracy theories in France (The Local.fr, 2018).

Cultural affinity and way of thinking plays a major role here. Israeli politician, human rights activist Natan Shcharanskyi described Soviet people, motivation and ideology: "the Soviet Union was a country that 
tried to create a breed of people without memory, to deprive them of their identity. And these extreme forms of Bolshevism, which led to the deaths of tens of millions of people, are returned today in the form of postmodernism, without proletarian dictatorship, but with the same idea that people without memory, without religion, without national solidarity, people for whom history means nothing - this is, they say, very good, because then there will be no wars. This is a dangerous philosophy, it makes life meaningless, and people are weak in the struggle for democracy and freedom. Memory is also about very difficult events, which are usually taught and educated much better than positive memories. If a person escapes from the memories of a personal tragedy, he ultimately becomes mentally ill. If a person has the courage to survive, that person becomes stronger. The same thing happens to peoples. Today, every great nation in Europe, including Ukraine, is engaged in a dialogue with itself. And this way of self-search is important. As knowledge of one's own history is an important part of the self-affirmation of the nation and the successful development of the country" (Shcharanskyi, 2017). Preserving safety of cultural and informational space, protection from aggressive irrational reality brought by Russian disinformation campaign and hate-policy, can be the best protection of democracy and sovereignty in the world (Herpen, 2015).

The totalitarian regimes are able to quickly consolidates and motivate people to wage a war and if the war is concealed, desinformation is widespread this make it difficult for liberal democracies to fight off the aggression. And whilst we believe that democracies don't wage a war with each other, but if state is autocratic it can use all means necessary to undermine rival national security of democratic state. People 'who feel relation to Russian culture', were used to conceal the aggression against Ukraines, disinformation played its role for as people in ex-USSR country have experienced and got used to distortion of the reality in information space. Current Russian Federation "sovereign democracy" cannot be successful either in peace - as court system is corrupt and personal freedom of Russian people is limited since the actually live in autocratic regime (Dobrowolski, Sułkowski 2020). But success is neither possible to wage an open war - as economical and technological dependence from the world is substantial and autocrathy will soon fall behind against free world that will stand united facing direct threat. But as we witness since 2014, Russian Federation has solved this dissonance since they didn't declare the war, but still wages it 6 years after as "covert-ops". Russian people are supporting this politics as the election of the Russian President in 2018 demonstrated. Despite Russian citizens know that their country wages the war with Ukraine or with Syria, but most don't admit it publicly, deny ongoing military aggression and adheres to the official agenda.

While war ideology in Russian Federation thrived, but the war was not declared and people in the world were misled by Russian propaganda, by distorted information and manipulation on the perception of events, which all states that the Russian Federation is not involved. While world democracies are getting tired of the situation since 2014, people around the world forget starting events, perspective is shifting as facts are still being substituted with disinformation. This shaping the reality technology has become widespread and as the result conspiracy theories are influencing voting decisions thus support of the populist slogans and leaders is increasing. At the same time Russian society keeps silence and does nothing to stop the disinformation war they started. It is obvious that information should not be misleading deliberately, and disinformation should be fought off. World is already opposing disinformation with fact-checking of the news and journalistic investigation counter-measures, but this effort is time-taking, demands resources and truth is not so popular as conspiracy disinformation agenda. At the same time cost and time effective technological methods to reduce the impact of disinformation - is deranking or even banning the sources of disinformation in Internet media and search engines (BBC News, 2017), (Hern, 2017). Together with technology satire shows effectiveness more than scientific, logical or fact-proof approach in direct intellectual fight with disinformation. Satire, as a simple manifestation of critical thinking, works better for those not engaged in following the conspiracy theories which are based on emotions, but not on logic or science. 
But as world classic liberal ideology is weakened and filled with leftist ideas, which are especially influential in postmodernism era and post industrialism and as 100 years before, new ideas of social life modernization can again lead to shifting the policy toward new age of conquering the world. We need to identify and oppose these attempts before they distort the perception of a big number of people and become too strong to overcome without bloody sacrifice as it happened in the 20 century. 'New orders' of 21 century have modified old imperialistic ideas of unsustainable world political systems. The 'Russian World' narrative is constructed on the basis of post-truth and imperialistic conquest and is reincarnating anti democratic trends same way it happened 100 years before, when idea of Nazism and Communism were born.

\section{REFERENCES}

Applebaum, A. (2016). The Dutch just showed the world how Russia influences Western European elections. Retrieved 06.08.2018 from https://www.washingtonpost.com/opinions/russias-influence-in-westernelections/2016/04/08/b427602a-fcf1-11e5-886f-a037dba38301 story.html.

BBC News. (21.11.2017). Google to 'derank' Russia Today and Sputnik. Retrieved 25.11.2017 from https://www.bbc.com/news/technology-42065644.

BBC News. (24.06.2014). Putin promises he will always "protect Russian people' at Ukraine [Путин обещает "защищать pyсcких" на Украине $\quad$ всегда]. $\quad$ Retrieved $\quad 27.07 .2014$ from https://www.bbc.com/russian/russia/2014/06/140624 putin deauthorisation ukraine reax.

Besançon, A. (2017). Holy Ruthenia (Russia) [Свята Русь]. Kyiv: Klio TOV, pp.1-112.

Bezmenov, Y. (1983). Yuri Bezmenov: Deception Was My Job (Complete). Retrieved 11.02.2020 from https://www.youtube.com/watch?v=AhAzGLb1j40.

Bilan, Y., \& Bilan, S. (2011). The Formation of Civil Society in Ukraine after the Orange Revolution. Economics \& Sociology, 4(1), 78-86.

Brzezinski, Z. (2000). The Grand Chessboard. Lviv - Ivano-Frankivsk: Lileia-NV, pp.87-123.

Cillizza, C. (2018). QAnon is the one conspiracy theory to rule them all. Retrieved 17.07.2018 from https://edition.cnn.com/2018/08/01/politics/qanon-trump.

Cunningham, S. (2017). Russian Has Become 'Second Language' Taught in Syrian Schools, Official Says. Retrieved 20.09.2017 from https://www.voanews.com/a/russian-second-language-syria-schools/3820328.html.

Curridori, F. (2018). The annexation of Crimea by Russia is legitimate [Salvini: "Legittima l'annessione della Crimea da parte della Russia"]. Retrieved 21.07.2018 from http://www.ilgiornale.it/news/politica/salvini-legittima-lannessionecrimea-parte-russia-1555802.html.

Desinformation review (2018). Keywords of Disinformation: Genocide, Nazi - and the World Cup. Retrieved 29.07.2018 from https:/ / euvsdisinfo.eu/keywords-of-disinformation-genocide-nazi-and-the-world-cup.

Dickinson, P. (2017). Why Is the International Media Still Repeating Kremlin Propaganda about Ukraine?. Retrieved 16.07.2018 from http://www.atlanticcouncil.org/blogs/ukrainealert/why-is-international-media-still-repeating-kremlinpropaganda-about-ukraine.

Dickinson, P. (2018). They speak Russian in Crimea, but that doesn't make it part of Russia. Retrieved 14.07.2018 from http://www.atlanticcouncil.org/blogs/ukrainealert/they-speak-russian-in-crimea-but-that-doesn-t-make-itpart-of-russia.

DiResta, R. (2018). The Digital Maginot Line. Retrieved 05.01.2019 from https://www.ribbonfarm.com/2018/11/28/the-digital-maginot-line/.

Dobrowolski, Z., \& Sułkowski, Ł. (2020). Implementing a Sustainable Model for Anti-Money Laundering in the United Nations Development Goals. Sustainability, 12(1), 244.

Etter, L. (2017). What bappens when the government uses Facebook as a weapon? Retrieved 09.01.2019 from https://www.bloomberg.com/news/features/2017-12-07/how-rodrigo-duterte-turned-facebook-into-aweapon-with-a-little-help-from-facebook.

EU vs Disinformation campaign [Euvsdisinfo.eu] (2018). Disinformation Cases. Retrieved 13.08.2018 from https://euvsdisinfo.eu/disinformation-cases/. 
EU vs Disinformation campaign [Euvsdisinfo.eu] (26.06.2018). Debumanizing disinformation as a weapon of the information war. Retrieved 20.07.2018 from https://euvsdisinfo.eu/dehumanizing-disinformation-as-a-weapon-of-theinformation-war/.

Fukuyama, F. (2010). The end of history and the last man. Moscow: AST: AST Moskva: Poligrafizdat, pp.267-506.

Gessen, M. (2018). The Photo Book That Captured How the Soviet Regime Made the Truth Disappear. Retrieved 1.08.2018 from https://www.newyorker.com/culture/photo-booth/the-photo-book-that-captured-how-thesoviet-regime-made-the-truth-disappear.

Giles, K. (2017). Handbook of Russian Information Warfare. Retrieved 14.04.2018 from http:/ / www.ndc.nato.int/news/news.php?icode $=995$.

Google Trends (2020). Retrieved from https://trends.google.com/trends/explore.

Hern, A. (2017). Google plans to 'de-rank' Russia Today and Sputnik to combat misinformation. Retrieved 25.11.2017 from https://www.theguardian.com/technology/2017/nov/21/google-de-rank-russia-today-sputnikcombat-misinformation-alphabet-chief-executive-eric-schmidt.

Herpen, M. (2015). Viiny Putina. Chechnia, Hruziia, Ukraina: nezasvoieni uroky mynuloho [Війни Путіна. Чечня, Грузія, Україна: незасвоєні уроки минулого]. Kharkiv: Vivat, p.60.

Herpen, M. (2015). Viiny Putina. Chechnia, Hruziia, Ukraina: nezasvoieni uroky mynuloho [Війни Путіна. Чечня, Грузія, Україна: незасвосні уроки минулого]. Kharkiv: Vivat, p.291.

Holopov, A. (12.10.2012). Holopov - Person in informational aggression environment (12.10.2012) [Холопов Человек в условиях информационной агрессии]. Retrieved 11.02 .2020 from https://www.youtube.com/watch?v=KbdlCY6cqHw.

Holopov, A. (2013). Person in informational aggression environment [Человек в условиях информационной агрессии]. Retrieved 12.10.2013 from https://www.youtube.com/watch?v=UdfLL296050.

Hurska, A. (2018). Pro-Russian Demonstrations in Riga: The 'Spanish Trace' and Potential Repercussions. Retrieved 08.05.2019 from https://jamestown.org/program/pro-russian-demonstrations-in-riga-the-spanish-trace-andpotential-repercussions/.

Huyssen, A. (1986). After the great divide: modernism, mass culture, postmodernism. Bloomington: Indiana University Press, pp. 216-221.

International Progress Organization (29 May 1987). THE GENEVA DECLARATION ON TERRORISM UN General Assembly Doc. A/42/307.

Khmara, S. (1975). Etnotsyd ukraintsiv v SRSR [Ethnocide of Ukrainians in USSR]. 7-8th. Paryzh - Toronto - Baltymor: Smoloskyp.

Language Magazine [languagemagazine.com] (30.05.2014). Syrian Offers Russian in All High Schools. Retrieved 20.09.2017 from https://www.languagemagazine.com/russian-language-to-become-compulsory-in-syrianschools.

Lapin, I. (2017). The Draft Law on Fence Collaboration [Проекm Закону про заборону колаборачіонізму]. Retrieved 13.03.2017 from http://w1.c1.rada.gov.ua/pls/zweb2/webproc4 1?pf3511=61312.

Margry, K. (1992). 'Theresienstadt' (1944-1945): The Nazi propaganda film depicting the concentration camp as paradise. Historical Journal of Film, Radio and Television, 2(2), 145-162.

Medvedev, S. (2014). Russian ressentiment [Русский ресентимент]. Retrieved 20.10.2014 from http://www.stranaoz.ru/2014/6/russkiy-resentiment.

Nazaccent.ru (25.06.2014). Putin declared protection of Russian-speaking people at Ukraine once again [Путин снова заявиц о защите русскоязычного населения на Украине]. Retrieved 27.07.2014 from http://nazaccent.ru/content/12147-putin-snova-zayavil-o-zashite-russkoyazychnogo.html.

Radio Svoboda. (2014). Meeting in Simferopol on February 26. Retrieved 26.02.2014 from https://www.svoboda.org/a/25278934.html.

Ross, C. (2018). Regional elections in Russia: instruments of authoritarian legitimacy or instability? Retrieved 20.07.2018 from: https://www.nature.com/articles/s41599-018-0137-1.

RT на русском [youtube.com] (17.04.2014). Putin: (we) Should provide interests of Russian-speaking people in south-eastern Ukraine [Путин: Необходимо обеспечить интересвг русскоязьчного населения югг-востока Украины]. Retrieved 17.04.2014 from https:/ / youtu.be/xq4FJsGTUo0?t=4m49s. 
Scharf, M. P., \& Szonert-Binienda, M. (2011). Katyn: Justice Delayed or Justice Denied-Report of the Cleveland Experts' Meeting. Case W. Res. J. Int'l L., 44, 535.

Shcharanskyi, N. (2017). The prophecies of Soviet dissidents about Ukraine have not come true yet Натан Щаранський: Пророитва радянських дисидентів про Украйну поки не справдилися]. Retrieved 20.12.2017 from https://www.dw.com/uk/a41076630.

Smetanina, S. (2017). There is more demand for the Russian language in Syria right now than ever before. Retrieved 29.07.2018 from https://russkiymir.ru/en/publications/226358.

Sovet Federatsii Federalnogo Sobraniya Rossiyskoy Federatsii (01.03.2014). Federation Council (Russia) approved Russian Armed Forces usage on Ukraine territory [Совет Федерачии дал согласие на использование Вооруженных Сил России на территории Украиныз]. Retrieved 01.03.2014 from: http://council.gov.ru/events/news/39851/.

Stokes, B. (2017). Language: The cornerstone of national identity. Retrieved 03.02.2017 from http://www.pewglobal.org/2017/02/01/language-the-cornerstone-of-national-identity/.

Stránský, M. (2011). Embellishment and the visit of the International Committee of the Red Cross to Terezin. Retrieved 3.02.2020 from https://www.holocaust.cz/en/history/events/embellishment-and-the-visit-of-the-internationalcommittee-of-the-red-cross-to-terezin/.

Sułkowski, Ł. (2017). Social capital, trust and intercultural interactions. In Intercultural Interactions in the Multicultural Workplace (pp. 155-171). Springer, Cham.

Sułkowski, Ł. (2019). On bullshit management-the critical management studies perspective. Economics and Sociology, 12(1), 302-312.

Sułkowski, Ł., \& Zawadzki, M. (2015). Critical discourse in contemporary management science. Folia Philosophica, 34.

The Local.fr (08.01.2018). From flat Earth to moon landings: How the French love a conspiracy theory. Retrieved 07.07.2018 from https://www.thelocal.fr/20180108/from-flat-earth-theory-to-the-moon-landings-what-the-frenchthink-of-conspiracy-theories. 